\title{
VALUES IN THE FAMILY THAT AFFECT THE YOUTH CHARACTER HABITUATION WITH THE MOTHER WORK
}

\author{
Dian Pertiwi Josua, Euis Sunarti, and Diah Krisnatuti \\ Bogor Agricultural University \\ Email: dian_pertiwijoshua@apps.ipb.ac.id
}

\begin{abstract}
Character education can be applied through various methods, including the internalization of values and character habituation. The purpose of this study was to analyze the characteristics of adolescents and families, family values, and character habituation; analyze the influence of adolescent and family characteristics, family values, on habituation of adolescent characters. Respondents in this study were 200 people with translation; 100 junior and senior high school students in the Sukmajaya Depok area, and mothers of these teens who work. Location selection uses purposive, and res pondents are selected by random sampling. The results of the analysis state that the highest family value internalized by working mothers in adolescents is the value of humility. Conversely, a low value is the value of family recognition through achievement. Another finding based on Partial Least Square analysis shows that family values that have a significant positive effect on adolescent character habituation are self-control and emotion $(p=0.029, t>1,96)$. While family values that have a significant negative effect are family recognition through achievement $(p=0.000, t>1,96)$, and humility $(p=0.042, t>1,96)$.
\end{abstract}

Keywords: family values, character habituation, partial least square (PLS)

\section{NILAI-NILAI DALAM KELUARGA YANG BERPENGARUH TERHADAP HABITUASI KARAKTER REMAJA DENGAN IBU BEKERJA}

\begin{abstract}
Abstrak: Pendidikan karakter dapat diterapkan melalui berbagai metode, di antaranya yaitu dengan internalisasi nilai dan habituasi karakter. Tujuan dari penelitian ini untuk menganalisis karakteristik remaja dan keluarga, nilai-nilai keluarga, dan habituasi karakter serta untuk menganalisis pengaruh karakteristik remaja dan keluarga, nilai-nilai keluarga, terhadap habituasi karakter remaja. Responden dalam penelitian ini sebanyak 200 orang dengan penjabaran: 100 siswa SMP dan SMA di wilayah Sukmajaya Depok, serta para ibu dari para siswa tersebut yang bekerja. Pemilihan lokasi menggunakan purposive, dan responden dipilih secara random sampling. Hasil analisis menyatakan nilai keluarga yang paling tinggi diinternalisasikan oleh ibu bekerja pada remaja yaitu nilai kerendahan hati. Sebaliknya, nilai yang rendah yaitu nilai pengakuan keluarga melalui prestasi. Temuan lain berdasar analisis Partial Least Square menunjukkan bahwa nilai-nilai keluarga yang berpengaruh positif signifikan terhadap habituasi karakter remaja yaitu kontrol diri dan emosi $(p=0.029, t>1,96)$. Sedangkan nilai keluarga yang berpengaruh negatif signifikan yaitu pengakuan keluarga melalui prestasi $(p=0.000, \mathrm{t}>1,96)$, dan kerendahan hati $(p=0.042, \mathrm{t}>1,96)$.
\end{abstract}

Kata Kunci: nilai keluarga, habituasi karakter, partial least square (PLS)

\section{INTRODUCTION}

Family is the most important thing and very important for each individual. A person will learn to start from the education obtained in his family. Likewise in the moral and character aspects, the family is the first character to form. Aware of the importance of family in character education, the Indonesian government through the Ministry of Education and Culture of the Republic of
Indonesia carried out a strengthening of character education (PPK) with synergy of heart (ethics), taste (aesthetics), and sports (kinesthetic) through engagement and collaboration between school, family, and community.

Values are one that can characterize a person and are not obtained only from genetics, but these values need to be internalized, socialized, and practiced in life. 
Value is the meaning and ideology of the family which is usually derived automatically. Educational values are first started in the family, and will only continue to the level of formal and informal education after the child is at the stage of being ready to continue education, the value in school will play a role in shaping one's character.

The values contained in the family and those studied by students must have consistency so as not to cause personality disorders. In value education in the family, a student is developing self-identity and recognizing what is right and wrong according to his beliefs. Family values, carried out before children formally attend school (Yaşaroğlu, 2016). Teenagers' beliefs about something that they think is right and wrong, are traditionally influenced by the family (Brannon, 2008). Family value is the main value that is highly trusted in a person.

Transmission of values from parents to adolescents is an indicator of the success of adolescents in accepting values, standards, and customs that apply in society, and believed by the family as a form of action that is right and good to be able to adapt to their social environment. In addition to through value education, the most effective character building process, through its habituation process by familiarizing adolescents to do good values that have been carried out earlier, exemplified, and become daily education from family, school, and society (Muchtarom, 2012).

The main focus on strengthening the character includes the background by preparing adolescents in facing the demographic bonus and as a preventive measure for the character's moral degradation. Demographic bonus is a phenomenon in which the current population of Indonesia, which is included in the productive age, is greater than the unproductive population so that at this time adolescents have great opportunities and their potential needs to be improved so they are ready to become the main actors in advancing the country.

Teenagers are required to be competitive human beings and have tough characters. Character formation in children is one of the roles, tasks, and functions of the family (Dermawan, Sunarti, \& Herawati, 2018. Socially, the family is expressed as the internalization of values. The urgency of researching character in adolescence is because, in adolescence, a person is in a time of transition and biological, cognitive, and social-emotional changes. In addition, adolescence is a time for someone to develop identity and independence (Padilla-Walker, 2007; Barni et al., 2011; Pasaribu, Hastuti, \& Alfiasari, 2013).

The method of character education in adolescents can be done in various ways, including through character habituation. Character habituation is defined as the thing that leads to conditioning so that someone will gladly carry out acts of virtue. The essence of character habituation lies in emphasizing the importance of one's affective response in conditions and conditions in the internal and external environment (Bowditch, 2008).

Before habituating characters, Aristotle (1944) who was the source of the theory of character habituation, stated that one must first feel the learning process, in this study learning through family values. Habituation has a concept of virtue and happiness. Someone who is habituating a character, he is not being accustomed to doing good in a pleasant way.

The urgency of researching family values and habituation of adolescent characters can also be seen based on social phenomena that begin to change as globalization progresses. Initially, a mother was 
positioned as a housewife with the main task of taking care of the needs of her husband and children. At present, another challenge for the habituation of adolescent characters, no longer only comes from the influence of peers, but internally itself and comes from the family environment. The success of value dissemination by working mothers, in adolescents, is also a factor that needs to be seen.

The meaning of values in character habituation, in studies that have been studied, is relevant to the value of education. So far, the application of values that are considered influential on the character of adolescents is learning in school. While the character habituation process, based on the values obtained from the family. Kemendiknas (2010) states that there are two methods of growing children's character, including through intervention and habituation. Interventions in character education lead to the integration of the realization of theory and the meaning of characters in the learning process through the Contextual Teaching and Learning approach so that the internalization of moral values is more easily understood. Meanwhile, habituation, obtained from the repetition of good activities and becomes a daily routine.

This research describes the relationship and influence of family values both directly and indirectly, especially values that are disseminated, internalized, and socialized according to family culture in Asia, towards habituation of adolescent characters. Familiarizing adolescents with good character cannot only see the success of the character education system as part of the teaching and learning process but also needs to analyze the extent to which families instill the first role in the habituation of adolescent characters. The family values referred to in this study are seen from the perspective of working mothers.

\section{METHOD \\ Research Design}

The research carried out was quantitative research, designed in a cross-sectional study, namely observational research, to see the results and exposure of respondents at the same time, the results of the study can be used in studying the relationship and attachment between phenomena and variables studied 2016. The location of this research was conducted in Depok City, which was developing in a city of family resilience. The research location was chosen based on purposive. Respondents who participated in the study were determined through random sampling.

\section{Population and Research Samples}

Respondents in this study were students and mothers as biological parents from five A-accredited schools, with a total number of 200 respondents from 100 students and 100 mothers. The sample of this study was middle and high school students who entered the age of adolescents with their parents, namely working mothers. Criteria for samples are taken based on: (1) aged 14-19 years; (2) having working mothers; (3) children and mothers living and living in one house; (4) sample families are intact families who are not divorced; and (5) willing to volunteer to be involved in research.

\section{Research Instruments}

The tools used to measure four variables. Research data was distributed to respondents who met the criteria, then distributed randomly. The following variables and types of research questionnaires. 
- Maternal characteristics (mother's age, mother's work, maternal education).

- Example characteristics (Age, gender, number of siblings, and birth order)

- The Revised Asian Values Scale (AVS-R) (Kim, Atkinson, \& Yang, 1999), to measure family values, contains 36 question items, a seven-dimensional likert scale that includes dimensions of conformity with norms, family recognition through achievement, self-control and emotions, collectivism, humility, and filial piety, and seen from the perspective of family values of the mother.

- Construct the character habituation questionnaire from the educational theories of the characters of Lickona, Schaps, and Lewis (2007), with 6 character pillars; caring, citizenship, trustworthiness, fairness, respect and responsibility, referring to the concept of good character according to Sunarti (2005) contains 35 likert scale questions, seen based on the habituation of teenage characters at home and at school.

While other data, which are secondary data obtained from the study of statistical literacy, and library studies through study journals conducted by previous researchers. The data obtained is then processed through the stages of editing, coding, scoring, entry, cleaning, analyzing and interpretation. The processing uses the help of Microsoft Excel, Windows Statistical Package for Social Science (SPSS), and SmartPLS 3.

\section{RESULTS AND DISCUSSION \\ Results}

\section{Characteristics of Adolescents and Families}

This study was conducted in two different types of schools in the Sukmajaya Depok area, namely junior and senior high schools and taking samples of different sexes. Table 1 describes the percentage of respondents' sexes with the type of school. Based on Table 1, more than three fifths (63.0) of the respondents were male, and the remaining nearly five fifths (37.0) of respondents were women. The average age of respondents is 16.19 years, with the description of education level as follows.

Table 1. Respondents According to Sex

\begin{tabular}{lcc}
\hline \multicolumn{1}{c}{ Category } & Amount (n) & Percentage (\%) \\
\hline Male & 63 & 63.0 \\
Female & 37 & 37.0 \\
Total & \multicolumn{2}{c}{100} \\
Mean \pm Std $(0-100)$ & \multicolumn{2}{c}{$1.37 \pm 0.48$} \\
\hline
\end{tabular}

Table 2 shows that more than two fifth (45.0) respondents are from junior high school, and more than half (55.0) are high school students. In addition, the respondents' family characteristics, the mother's age range of 43 years. According to Santrock (2007), mother's age is included in the adult age category. With an average of 13.24 years of education, which means the mother of the average respondent has graduated high school.

Table 2. Respondents According to Education Level

\begin{tabular}{lcc}
\hline \multicolumn{1}{c}{ Category } & Amount $(\mathrm{n})$ & Percentage (\%) \\
\hline SMP & 45 & 45.0 \\
SMA & 55 & 55.0 \\
Total & \multicolumn{2}{c}{100} \\
Mean \pm Std $(0-100)$ & \multicolumn{2}{c}{$1.45 \pm 0.50$} \\
\hline
\end{tabular}

The results of other studies stated that the type of family of respondents was small families with an average of 4 people in one family. Most of the respondents were firstborn (57.0), one fifth (34.0) were middleaged children, and less than one-tenth (9.0) were the youngest children. In addition, judging from the type of work of the mother who is distinguished from working for- 
mally and informally, the following is explained in Table 3.

As many as more than three fifths (64.0) respondent mothers work in the formal sector such as civil servants, private employees, and BUMN employees. While nearly two fifths (36.0) of mothers work in the informal sector such as PKK cadres, gymnastics instructors, selling online, freelance factory workers, and entrepreneurship.

Table 3. Types of Maternal Occupation

\begin{tabular}{lcc}
\hline \multicolumn{1}{c}{ Category } & Amount (n) & Percentage (\%) \\
\hline Formal & 64 & 64.0 \\
Informal & 36 & 36.0 \\
Total & \multicolumn{2}{c}{100} \\
Mean \pm Std (0-100) & \multicolumn{2}{c}{$7.44 \pm 1.75$} \\
\hline
\end{tabular}

\section{Family Values}

Value is a goal that motivates individuals and gives an influence on attitudes, behavior, and evaluation. In a cultural perspective, values show the systematics of individual structures and cultural variations. Value has a function for psychological adaptation. The internal structure of values pertains to certain systems (Fischer \& Boer, 2016). Value is something abstract, contains the desired behavioral model or the final condition to be addressed (Maio, 2016).

Values can also be defined as internal systems that are structured so that individuals can regulate their environment and social life. Individual changes and behavior are related to certain values and culture. Philosophically, value is a sociological tradition that regenerates systems between generations (Thornhill \& Fincher, 2014).
Table 4. Distribution, Minimum, Maximum, Average, and Standard of Family Value Devotion

\begin{tabular}{|c|c|c|}
\hline Category & $\begin{array}{l}\text { Amount } \\
\text { (n) }\end{array}$ & $\begin{array}{c}\text { Percentage } \\
(\%) \\
\end{array}$ \\
\hline \multicolumn{3}{|l|}{ A. Conformity with norm } \\
\hline Low $(<60)$ & - & - \\
\hline Medium (60-80) & 90 & 90.0 \\
\hline Height $(>80)$ & 10 & 10.0 \\
\hline Total & \multicolumn{2}{|c|}{100} \\
\hline Minimum-maximum (0-100) & \multicolumn{2}{|c|}{$60.00-91.00$} \\
\hline Mean \pm Std $(0-100)$ & \multicolumn{2}{|c|}{$73.76 \pm 8.36$} \\
\hline \multicolumn{3}{|c|}{ B. Family recognition through achievement } \\
\hline Low $(<60)$ & 89 & 89.0 \\
\hline Medium (60-80) & 1 & 1.0 \\
\hline Height $(>80)$ & 10 & 10.0 \\
\hline Total & \multicolumn{2}{|c|}{100} \\
\hline Minimum-maximum (0-100) & \multicolumn{2}{|c|}{$10.00-80.00$} \\
\hline Mean \pm Std $(0-100)$ & \multicolumn{2}{|c|}{$37.80 \pm 16.30$} \\
\hline \multicolumn{3}{|l|}{ C. Self-control and emotion } \\
\hline Low $(<60)$ & - & - \\
\hline Medium (60-80) & 19 & 19.0 \\
\hline Height $(>80)$ & 81 & 81.0 \\
\hline Total & \multicolumn{2}{|c|}{100} \\
\hline Minimum-maximum (0-100) & \multicolumn{2}{|c|}{$67.0-100$} \\
\hline Mean \pm Std $(0-100)$ & \multicolumn{2}{|c|}{$86.96 \pm 10.02$} \\
\hline \multicolumn{3}{|l|}{ D. Collectivism } \\
\hline Low $(<60)$ & 27 & 27.0 \\
\hline Medium (60-80) & 43 & 43.0 \\
\hline Height $(>80)$ & 30 & 30.0 \\
\hline Total & \multicolumn{2}{|c|}{100} \\
\hline Minimum-maximum (0-100) & \multicolumn{2}{|c|}{$30.0-90.0$} \\
\hline Mean \pm Std $(0-100)$ & \multicolumn{2}{|c|}{$66.60 \pm 14.58$} \\
\hline \multicolumn{3}{|l|}{ E. Humility } \\
\hline Low $(<60)$ & - & - \\
\hline Medium (60-80) & 31 & 31.0 \\
\hline Height $(>80)$ & 69 & 69.0 \\
\hline Total & \multicolumn{2}{|c|}{100} \\
\hline Minimum-maximum (0-100) & \multicolumn{2}{|c|}{$70.0-100$} \\
\hline Mean \pm Std $(0-100)$ & \multicolumn{2}{|c|}{$88.80 \pm 13.20$} \\
\hline \multicolumn{3}{|l|}{ F. Dedicated } \\
\hline Low $(<60)$ & 9 & 9.0 \\
\hline Medium (60-80) & 28 & 28.0 \\
\hline Height $(>80)$ & 63 & 63.0 \\
\hline Total & \multicolumn{2}{|c|}{100} \\
\hline Minimum-maximum (0-100) & \multicolumn{2}{|c|}{$53.00-93.00$} \\
\hline Mean \pm Std $(0-100)$ & 74.8 & $0 \pm 13.24$ \\
\hline G. Universal & & \\
\hline Low $(<60)$ & - & - \\
\hline Medium (60-80) & 69 & 69.0 \\
\hline Height $(>80)$ & 31 & 31.0 \\
\hline Total & & 100 \\
\hline Minimum-maximum (0-100) & 62.0 & $0-85.00$ \\
\hline Mean \pm Std $(0-100)$ & 73. & $8 \pm 5.93$ \\
\hline
\end{tabular}

Table 4 shows that in this study the largest family values internalized by adolescents from working mothers are the value of 
humility (88.80) and the lowest value is family recognition through achievement. Fourteen (90.0) mothers agree that adolescents should be introduced with values according to the prevailing norms and have self-control and emotion.

Meanwhile, for the value of internalized internal collectivism, more than twofifth respondents (43.0) belong to the medium category. At devoted values, more than three fifths (63.0) belong to a high category, and with a universal value of more than one fifth (31.0) included in the high category.

\section{Habituation Character}

Character of a person can be formed through social norms that come from the environment and genetically. A good environment, as well as good genetics, can form and develop the character of goodness in a person. Social norms are defined as social values in the social environment in which individuals live, develop, and get an education (Irjanti \& Setiawati, 2018).

Character education through habituation can be done with the process of sharpening, nurturing, and fostering. The learning model is based on studies that have been done before, able to build students' character (Wahyuningsih, Sutarno, \& Rochsantiningsih, 2017). However, the effectiveness of character education in schools is stated to still need to be adapted to the conditions of students. In addition, another obstacle of character education in schools is an implementation that is not relevant to human resource readiness, availability of facilities, and lack of family support.

Based on the results of the study (See Table 5), the character habituation of students with working mothers is classified as high (66.0), and more than one fifth (34.0) respondents are habituated to their charac- ters in the medium category. The high character habituation in adolescents, even with working mothers, is because the character habituation factor in adolescent students is not fully based on parents, but rather the result of synergy between educating characters in the family, role models of teachers in school, peer relationships, and role models idolized by teenagers.

\section{Table 5. Distribution, Minimum Values, Maximum Values, Average Val- ues, and Standards of Devotion Character Habituation}

\begin{tabular}{lcc}
\hline \multicolumn{1}{c}{ Category } & Amount (n) $\begin{array}{c}\text { Percentage } \\
(\%)\end{array}$ \\
\hline Low $(<60)$ & - & - \\
Medium $(60-80)$ & 34 & 34.0 \\
Height $(>80)$ & 66 & 66.0 \\
Total & \multicolumn{2}{c}{100} \\
Minimum-maximum & \multicolumn{2}{c}{$71.00-88.00$} \\
$(0-100)$ & \multicolumn{2}{c}{$80.75 \pm 4.11$} \\
Mean \pm Std $(0-100)$ &
\end{tabular}

\section{Relationship between Family Characteris- tics, Characteristics of Adolescents, Family Values, and Character Habituation}

The results of a test of the relationship between family characteristics, adolescent characteristics, and independent variables of this study show some results. In table 6, it can be seen that there is a significant negative relationship between the value of family service and the working hours of the mother, meaning that the less time the mother has, the lower the value of the family in terms of dedication to adolescents. At the age of the mother, the value of self-control and emotion is significantly negative, thus the age of the younger mother, will be related to the lack of family values of aspects of self-control and emotions that are internalized in children.

Meanwhile, maternal age is signifycantly positively related to character habi- 
tuation, where mature mother's age will be related to the mother's ability to provide positive character habituation in adolescents. Maternal education, is significantly positively related to family values of conformity with norms, thus higher educated mothers will more often instill family values relating to community norms in adolescents. The findings of other studies indicate that adolescence is positively and significantly related to family values in aspects of family recognition through achievement. Which can also be interpreted, the higher the age of the teenager, the working mother will be more demanding the child to be more accomplished.

Table 6. Correlation Coefficients Between Family Characteristics, Student Characteristics, Habituation of Characters

\begin{tabular}{|c|c|c|c|c|c|c|c|c|}
\hline Variable & $\begin{array}{l}\text { Confor- } \\
\text { mity with } \\
\text { norm }\end{array}$ & $\begin{array}{c}\text { Family } \\
\text { recognition } \\
\text { through } \\
\text { achieve- } \\
\text { ment }\end{array}$ & $\begin{array}{l}\text { Self- } \\
\text { control } \\
\text { and } \\
\text { emotion }\end{array}$ & $\begin{array}{l}\text { Collecti- } \\
\text { vism }\end{array}$ & Humility & Dedicated & Universal & $\begin{array}{l}\text { Character } \\
\text { Habituation }\end{array}$ \\
\hline $\begin{array}{l}\text { Maternal } \\
\text { working } \\
\text { hours }\end{array}$ & -0.022 & 0.020 & -0.038 & 0.126 & -0.165 & $-0.312^{* *}$ & -0.146 & 0.053 \\
\hline $\begin{array}{l}\text { Maternal } \\
\text { education }\end{array}$ & $0.262^{* *}$ & 0.105 & 0.143 & 0.137 & 0.046 & -0.037 & -0.121 & 0.185 \\
\hline Maternal age & -0.088 & -0.125 & $-0.240^{*}$ & 0.003 & -0.040 & -0.024 & -0.047 & $0.617^{*}$ \\
\hline $\begin{array}{l}\text { Adolescent } \\
\text { sex }\end{array}$ & 0.097 & 0.027 & 0.107 & 0.023 & -0.025 & 0.010 & 0.028 & -0.196 \\
\hline $\begin{array}{l}\text { Adolescent } \\
\text { age }\end{array}$ & -0.111 & $0.955^{* *}$ & -0.139 & -0.073 & -0.040 & -0.024 & -0.066 & -0.157 \\
\hline
\end{tabular}

\section{The Influence between Variables Researched}

The influential factors in this study were analyzed using Partial Least Square (PLS) analysis. PLS analysis can be done if it meets the inner and outer model requirements. After testing, it is known that the indicators in this study have not met the requirements for validity and reliability on family characteristics and adolescent characteristics (Table 7).

To fulfill these requirements, the variables are evaluated and those that do not meet reliability are $\geq 0.70$ and AVE $>0.50$, omitted. Based on the evaluation, variables that do not meet the requirements are; family characteristics (mother's working hours, mother's education, and mother's age) and adolescent characteristics (birth order).

The final model influences family characteristics, student characteristics, family values, and character habituation has the value of outer loading $>0.5$, meaning that the indicator is valid and can describe the variables studied. The model in this study can explain the character habituation variable of 0.249 , meaning that 24.9 percent of the variables studied affect the character habituation variable, the remaining 75.1 is influenced by other variables (See table 9). Effect analysis can be done after conducting a model test analysis. 
Based on the analysis carried out, and evaluation, the model in each variable as a whole has been feasible to test its influence. Table 10 states that family characteristics (mother's education and mother's working hours (loading value, $t>1.96$ ) have a significant positive effect on character habituation, which means that the higher the mother's education and the better the time management for the mother, the better habituation student character.

Other research findings show that adolescent characteristics (student age) (loading value, $t>1.96$ ) have a significant negative effect on character habituation, which means that the younger the student's age the family values and character habituation are minimal. The value of family recognition is significantly negatively related to character habituation (loading value, $t>1.96$ ), which indicates that the more a student is recognized for his achievement by his family, the habituation of his character will be lower.
Table 7. Value of Outer Loading Initial Model Influences Family Characteristics, Student Characteristics, Family Values, and Habituation of Characters

\begin{tabular}{lc}
\hline \multicolumn{1}{c}{ Variable } & $\begin{array}{c}\text { Nilai } \\
\text { outer } \\
\text { loading }\end{array}$ \\
\hline $\begin{array}{l}\text { Family value index conformity } \\
\text { with norms }\end{array}$ & 1.000 \\
$\begin{array}{l}\text { Family value index family } \\
\text { recognition through achievement }\end{array}$ & 1.000 \\
$\begin{array}{l}\text { Family value index self-control and } \\
\text { emotions }\end{array}$ & 1.000 \\
$\begin{array}{l}\text { Family value index collectivism } \\
\text { Family value index humility }\end{array}$ & 1.000 \\
$\begin{array}{l}\text { The dedicated family value index } \\
\text { The universal family value index }\end{array}$ & 1.000 \\
$\begin{array}{l}\text { Habituation index character } \\
\text { Mother's working hours <- Family } \\
\text { characteristics }\end{array}$ & 1.000 \\
$\begin{array}{l}\text { Mother's work type <- Family } \\
\text { characteristics }\end{array}$ & -0.005 \\
$\begin{array}{l}\text { Mother's education <- Family } \\
\text { characteristics }\end{array}$ & 0.794 \\
$\begin{array}{l}\text { Mother's age <- Family } \\
\text { characteristics }\end{array}$ & 0.325 \\
$\begin{array}{l}\text { Gender <- Characteristics of } \\
\text { teenagers }\end{array}$ & -0.417 \\
$\begin{array}{l}\text { Order of birth <- Characteristics of } \\
\text { adolescents }\end{array}$ & -0.526 \\
$\begin{array}{l}\text { Age <- Characteristics of } \\
\text { adolescents }\end{array}$ & 0.686 \\
\hline & \\
\hline
\end{tabular}

Table 8. The Initial Value of Average Variance Extracted and Composite Reliability Model of Family Characteristics, Adolescent Characteristics, Family Values, Against Habituation of Characters

\begin{tabular}{lcc}
\hline \multicolumn{1}{c}{ Variable } & $\begin{array}{c}\text { Average Variance } \\
\text { Extracted } \\
\text { (AVE)value }\end{array}$ & $\begin{array}{c}\text { Composite } \\
\text { reliability } \\
\text { value }\end{array}$ \\
\hline $\begin{array}{l}\text { Character habituation } \\
\text { Family value index conformity with norms }\end{array}$ & 1.000 & 1.000 \\
Family value index family recognition through achieve- & 1.000 & 1.000 \\
ment & 1.000 & 1.000 \\
Family value index self-control and emotions & & \\
Family value index collectivism & 1.000 & 1.000 \\
Family value index humility & 1.000 & 1.000 \\
The dedicated family value index & 1.000 & 1.000 \\
The universal family value index & 1.000 & 1.000 \\
Family characteristics & 1.000 & 1.000 \\
Adolescent characteristics & 0.232 & 0.145 \\
\hline
\end{tabular}


Table 9. The Final Outer Loading Model Influences Family Characteristics, Student Characteristics, Family Values, and Habituation

\begin{tabular}{lc}
\hline \multicolumn{1}{c}{ Variable } & $\begin{array}{c}\text { Outer loading } \\
\text { value }\end{array}$ \\
\hline Character habituation & 1.000 \\
Family value index conformity with norms & 1.000 \\
Family value index family recognition through achievement & 1.000 \\
Family value index self-control and emotions & 1.000 \\
Family value index collectivism & 1.000 \\
Family value index humility & 1.000 \\
The dedicated family value index & 1.000 \\
The universal family value index & 1.000 \\
Mother's education <- Family characteristics & 0.778 \\
Mother's working hours <- Family characteristics & 0.804 \\
Age <- Characteristics of adolescents & 1.000 \\
\hline
\end{tabular}

Table 10. The Results of Decomposition Influence the Family Characteristics of Adolescent Characteristics, and Family Values on Character Habituation

\begin{tabular}{lccc}
\hline \multicolumn{1}{c}{ Variable } & $\begin{array}{c}\text { Direct } \\
\text { influence }\end{array}$ & $\begin{array}{c}\text { Indirect } \\
\text { influence }\end{array}$ & Total influence \\
\hline Family characteristics & $0.185^{*}$ & -0.026 & $0.159^{*}$ \\
Adolescent characteristics & $-0.138^{*}$ & -0.025 & $-0.163^{*}$ \\
Family value index conformity with norms & 0.159 & - & 0.159 \\
Family value index family recognition through & $-0.500^{*}$ & - & $-0.500^{*}$ \\
achievement & & & \\
Family value index self-control and emotions & $0.287^{*}$ & - & $0.287^{*}$ \\
Family value index collectivism & -0.226 & - & -0.226 \\
Family value index humility & $-0.355^{*}$ & - & $-0.355^{*}$ \\
The dedicated family value index & 0.016 & - & 0.016 \\
The universal family value index & 0.093 & - & 0.093 \\
\hline \multicolumn{2}{c}{$\mathrm{R}^{2}$} & & \multicolumn{2}{c}{0.249} \\
\multicolumn{1}{c}{$\mathrm{Ndj} \mathrm{R}^{2}$} & & \multicolumn{2}{c}{200} \\
\hline
\end{tabular}

Description: * Significant at $\mathrm{t}>1.96$

Another family value found to have a significant positive effect on character habituation is self-control value (loading value, $t>1.96$ ), which means that the more often the value is internalized by the family, the better the character habituation of students. On the contrary, the value of humility based on the results of the study is stated to have a significant direct effect on character habituation, where each student who has bad humility will have an impact on the poor habituation of the character that is in him (See picture 1).
The results of other studies indicate that there are indirect effects of family characteristics variables (mother's education and mother's working hours) as well as adolescent characteristics (student age) towards student character habituation. Every 1 increase in the value of conformity with the norm, will increase character habituation by 3.8 percent. Each decrease in 1 family recognition value through achievement, will reduce 0.6 percent of student character habituation. 
Every increase in 1 value of self-control and emotions, will increase character habituation by 2.5 percent. In addition, every decrease in the value of collectivism 1 decreases character habituation by 3.4 percent. Every decrease in 1 value of humility will reduce character habituation by 0.6 percent. Each increase in 1 filial value, will increase character habituation by 4.7 percent, and every increase in 1 universal value, will increase the habituation of student characters by 3.1 percent (Picture 1).

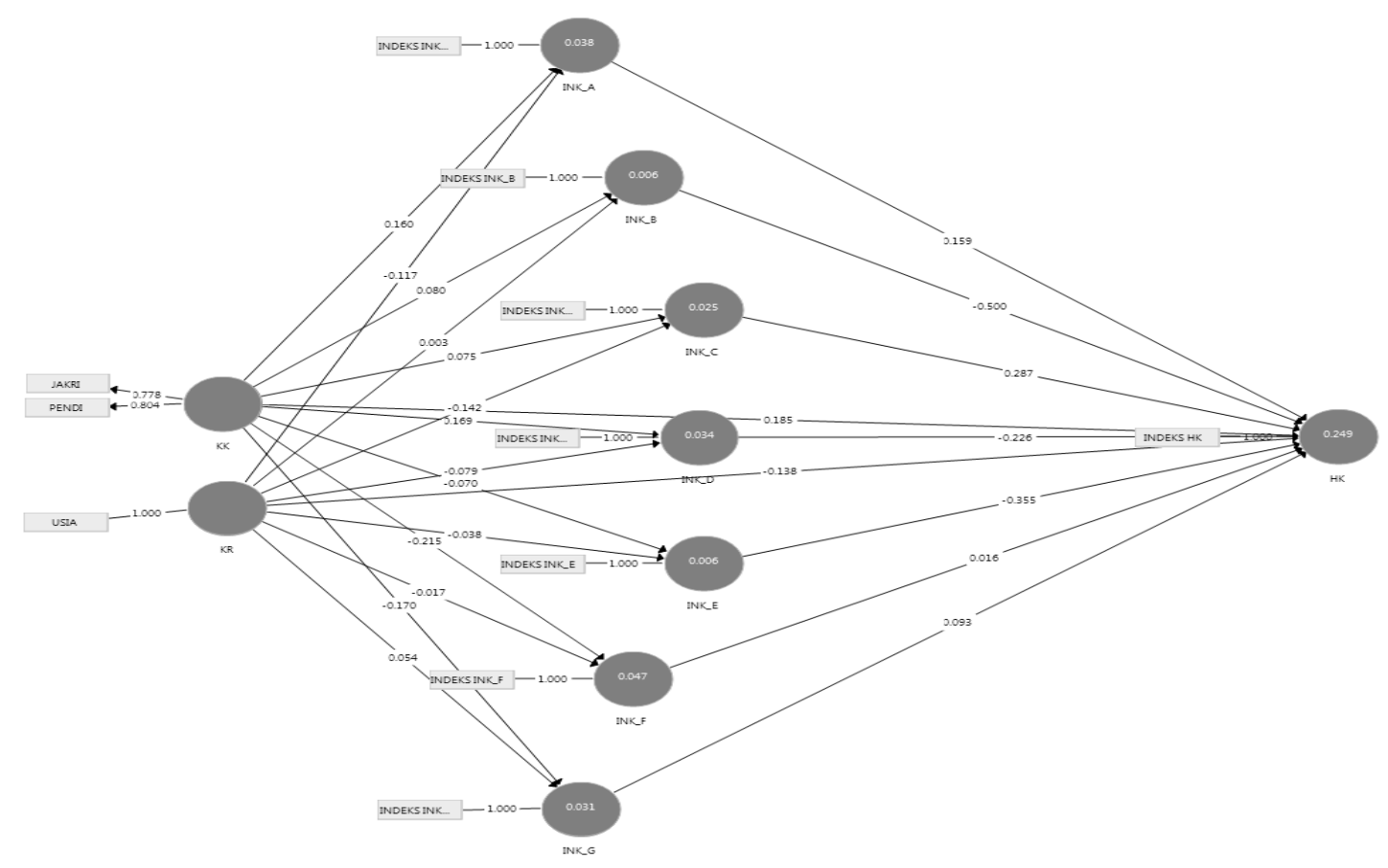

Figure 1. The Results of Path Analysis Influence the Variables Studied

\section{Discussion}

Transfers of values between generations is the goal of socialization and one that supports individual development and becomes education for someone to understand its function in society (Ranieri and Barni, 2012; Schönpflug, 2001). Value socialization for parents is central to family studies because family values shape parents 'practices and become parents' determinants in educating children and regulating the home environment for children (Tulviste, 2013; Kikas, Tulviste, \& Peets, 2014).

In this study, family characteristics can only be described by the mother's working hours and mother's education. while in the characteristics of adolescents, seen from the age of students. These variables are obtained because the outer loading value reaches more than 0.5 , according to the PLS rules. The test results of the relationship between family characteristics, adolescent characteristics, family values, and habituation of characters found that mother's working hours and maternal education are related to family values. Another correlation test results, states that maternal age is associated with character habituation, and adolescent characteristics associated with family values are adolescents.

This study aims to see the effect of family characteristics, adolescent characterristics, family values on character habituation. From this study, it was found that student character habituation was high. In other words, adolescents feel that the habituation of good character that has been internalized by the family, the example of 
the teacher, and their peers encourage students to make good character habituation. The greatest value internalized by the family in students is the value of self-control and emotion. This shows the family wants and has an idealism that a teenager must be better able to control themselves and their emotions.

In line with moral philosophy which states that moral education and character in a professional manner must bind and take root in emotions and experiences possessed by students in social learning between friends (Sanderse, 2018). In addition, the situation of character habituation includes processes (1) where educators stimulate by giving and explaining the truth; (2) both educators and students, show that virtue involves one's emotions and the ability of individuals to judge rationally about a person's emotional actions or reactions, and understand the intentions of those actions logical and emotional; and (3) character habituation requires someone to understand his emotions, actions in a fair, simple, courageous, and steady understanding of virtue (Curzer, 2012).

In habituation characters, the character of moral character education can be indicated by the expression of the child in the act of caring, regretting, entertaining, and returning toys borrowed from other children. Since the age of children, individuals are accustomed to sublime characters that tend to be open, so that in character habituation, children learn to adapt their character to the basic characters that parents use to justify rules based on family values that are the parents' goals (Sanderse, 2018).

Based on the test results of factors that influence character habituation, it was found that family characteristics, adolescent characteristics, family recognition values for achievement, self-control and emotional values, and heart-warming values directly influence character habituation. In accordance with previous studies, character education is not only based on understanding and knowledge but through the habituation process (Al Ghazali, 1997; Attaran, 2015).

\section{CONCLUSION}

In this study, character habituation was allegedly influenced directly and indirectly by family characteristics, adolescent characteristics, and family values. The results of the study show that the average family value that is internalized by the family varies. However, there is the highest family value and the expectation of parents for their teenagers, namely in the form of selfcontrol and emotion, humility, and filial values. The family values, contributing to the habituation of student characters, so that the tendency of adolescent behavior is a result of the process of internalizing values in the family.

If the value can be understood by adolescents, it will produce character habituation that is in accordance with the expectations and principles of the family. Conversely, if the family values that are implanted are not or difficult to understand by adolescents, then it will provide poor character education to students. In addition, the application of character education should be carried out integratively, between family and school. The role of the family in character education, including through family values.

In addition, this study states that although mothers are career women and work both formally and informally, they can still contribute to adolescent character education through socialization and the transfer of values that are family goals, so that a child can adapt and be accepted by the community. A mother's education, in this 
study, is stated to be related to values constructed in the family. While maternal age correlates in character habituation in students who are teenagers. Values in the family that are considered less important by career mothers, to internalize adolescence is the value of family recognition of achievement.

\section{ACKNOWLEDGMENTS}

The author would like to thank Depok's FOKLA (Eligible City Forum) for technical, administrative, and participatory assistance in preparing and during the conduct of research. In addition, thanks and awards were given to the editors of the Character Education Journal who have provided useful reviews and input on the publication of the results of this study. The results in this research journal are part of the thesis written by the author, under the guidance of Prof. Dr. Ir. Euis Sunarti, M.Si and Dr. Ir. Diah Krisnatuti., M.M.

\section{REFERENCES}

Al Ghazali. (1997). Mutiara ihya ulumuddin. Bandung: Mizan.

Aristotle. (1944). Politics. (H. Rackham, Trans.). Cambridge, MA: Harvard University Press.

Attaran, M. (2015). Moral education, habituation, and divine assistance in view of ghazali. Journal of Research on Christian Education, 24(1), 43-51. DOI: 10.1080/10656219.2015.1008083.

Barni, D., Ranieri, S., Scabini, E., \& Rosnati, R. (2011). Value transmission in the family: do adolescents accept the values their parents want to transmit? Journal of Moral Education, 40(1), 105121. DOI: https://doi.org/10.1080/03057240.2011 .553797$.

Bowditch, N. (2008). Aristotle on habituation: The key to unlocking the Nico- machean ethics. Ethical Perspectives, 15(3), 309-342. RETRIEVED FROM: http:/ / www.ethical-perspectives.be/viewpic.php?LAN=E\&TABLE=EP\& $\mathrm{ID}=1115$.

Brannon, D. (2008). Character education: It's a joint responsibility: Instilling positive character traits in children requires teachers, parents, and administrators to work together. Kappa Delta Pi Record, 44(2), 62-65. DOI: 10. 1080/00228958.2008.10516496.

Curzer, H. (2012). Aristotle $\mathcal{E}$ the virtues. Oxford: Oxford University Press.

Dermawan, S., Sunarti, E., \& Herawati, T. (2018). Internalisasi nilai kebaikan melalui fungsi keagamaan dan pengondisian lingkungan dan dampaknya terhadap karakter anak. Jurnal Ilmu Keluarga \& Konsumen, 10(3), 204-215. DOI: https:/ /doi.org/10.24156/jikk.2017.10.3.204.

Fischer, R., \& Boer, D. (2016). Values: The dynamic nexus between biology, ecology and culture. Current Opinion in Psychology, 8, 155-160. DOI: https://doi.org/10.1016/j.copsyc.2015.12.009.

Irjanti, R., \& Setiawati, F. A. (2018). Pengaruh nilai-nilai karakter terhadap prestasi belajar di SDIT Salman Al Farisi. Jurnal Pendidikan Karakter, 8(1), 40-50. DOI: https://doi.org/10.21831/jpk.v 8i1.21490.

Kemendiknas. (2010). Panduan Pendidikan Karakter di Sekolah Menengah Pertama. Jakarta: Ditjen Dikdasmen.

Kikas, E., Tulviste, T., \& Peets, K. (2013). Socialization values and parenting practices as predictors of parental involvement in their children's educational process. Early Education and Development, 25(1), 1-18. DOI: 10.1080/10409289.2013.780503. 
Kim, B. S., Atkinson, D. R., \& Yang, P. H. (1999). The Asian Values Scale: Development, factor analysis, validation, and reliability. Journal of counseling Psychology, 46(3), 342-352. DOI: 10.1037/0022-0167.46.3.342.

Lickona, T., \& Schaps, E. \& Lewis, C. (2007). Eleven Principles of Effective Character Education. Character Education Partnership.

Maio, G. R. (2016). The psychology of human values. London: Routledge.

Muchtarom, M. (2012). Strategi penguatan nilai-nilai Pancasila melalui inovasi pembelajaran PKn berorientasi civic knowledge, civic disposition, dan civic skill di perguruan tinggi. PKn Progresif, 7(2), 114-130. Retrieved from: https://www.researchgate.net/publi cation/315781876_strategi_penguata n_nilai-nilai_pancasila_melalui_inovasi_pembelajaran_pkn_berorientasic ivic_knowledgecivic_disposition_dan civic_skilldi_perguruan_tinggi.

Padilla-Walker, L. M. (2007). Characteristics of mother-child interactions related to adolescents' positive values and behaviors. Journal of Marriage and Family, 69(3), 675-686. DOI: https:// doi.org/10.1111/j.1741-3737.2007.00399.x.

Pasaribu, R. M., Hastuti, D., \& Alfiasari, A. (2013). Gaya pengasuhan permisif dan rendahnya sosialisasi nilai dalam keluarga berisiko terhadap penurunan karakter remaja. Jurnal Ilmu Keluarga $\mathcal{E}$ Konsumen, 6(3), 163-171. DOI:https:// doi.org/10.24156/jikk.2013.6 .3.163.

Ranieri, S. \& Barni, D. (2012). Family and other social contexts in the intergenerational transmission of values. $F a-$ mily Science, 3(1), 1-3. DOI: 10.1080/19424620.2012.714591.
Sanderse, W. (2018). Does Aristotle believe that habituation is only for children? Journal of Moral Education, 5 September, 1-13. DOI:10.1080/03057240.2018.1497952.

Santrock, J. W. (2007). Life-span development. New York, US: McGraw-Hill.

Schönpflug, U. (2001). Intergenerational transmission of values. The role of transmission belts. Journal of CrossCultural Psychology, 32(2), 147-185. DOI:https://doi.org/10.1177/002202 2101032002005.

Sunarti, E. (2005). Menggali kekuatan cerita. Jakarta: PT Elek Media Komputindo.

Thornhill, R., \& Fincher, C.L. (2014). The parasite-stress theory of values and sociality: Infectious disease, history and human values worldwide. Springer.

Tulviste, T. (2013). Socialization values of mothers and fathers: Does the child's age matter? Trames, 67/62(2), 129-140. DOI: 10.3176/tr.2013.2.02.

Wahyuningsih, S., Sutarno, S.Y., \& Rochsantiningsih, D. (2017). Development of among (asah, asih, asuh (a3)) systembased habituation learning model throygh playing games to build young learner's character. International Journal of Education and Psychology in the Community, 7(1/2), 83-94. Retrieved from: https://search.proquest.com/openview/494f21b63929a e7ab452c0eb43d77509/1?pq-origsite=gscholar\&cbl=1606375.

Yaşaroğlu, C. (2016). Cooperation and importance of school and family on values education. European journal of multidisciplinary studies, 1(2), 66-71. DOI: 10.26417/ejms.v1i2.p66-71. 